\title{
ANALISIS YURIDIS SIFAT KEILMUAN ANTROPOLOGI HUKUM DAN PERKEMBANGANNYA
}

\author{
Nama : Divo Mardodikso Hadi \\ Email : divomardodiksohadi18@gmail.com \\ No. BP : 1710003600063 \\ UNIVERSITAS EKASAKTI
}

\section{A. PENDAHULUAN}

\section{Latar Belakang}

Antropologi sebagai disiplin ilmu terus berkembang, tidak hanya pada tataran teoritis tetapi juga sebagai ilmu terapan yang mampu memberikan masukan bagi para pembuat keputusan dalam menentukan kebijakan pembangunan. Di Indonesia, perkembangan antropologi sebagai disiplin ilmu yang dipelajari para mahasiswa di perguruan tinggi masih tergolong baru. Salah satu tokoh penting dalam perkembangan antropologi di Indonesia adalah Koentjaraningrat, sehingga dapat dikatakan bahwa ia merupakan bapak antropologi di Indonesia (Suparlan, 1988).

Secara historis, antropologi berkembang dari suatu deskripsi hasil-hasil laporan perjalanan para penjelajah dan penjajah tentang kehidupan manusia di daerah yang disinggahi para penjelajah, atau kehidupan salah satu suku bangsa yang tinggal di daerah jajahan. Deskripsi tersebut dikenal dengan nama etnografi. Dalam perjalanannya kemudian, antropologi berkembang sebagaimana keberadaannya sekarang baik di negara-negara Eropa Barat, Amerika maupun di Asia. Beberapa cabang antropologi yang dikenal secara luas saat ini adalah antropologi fisik atau 
biologi, antropologi sosial, dan antropologi budaya. Di sisi yang lain, antropologi juga merupakan bidang ilmu terapan sehingga hasil kajiannya dapat dimanfaatkan sebagai masukan dalam pengambilan keputusan untuk keperluan pembangunan, terutamadalam pembangunan sosial budaya, seperti antropologi pembangunan, antropologi kesehatan, antropologi ekonomi, dan sebagainya. Adapun hal hal yang akan dibahas pada makalah ini adalah bagaimana kita mengetahui manfaat manfaat apa saja yang terkandung di dalam Ruang lingkup antropologi hukum.

Perkembangan Antropologi Hukum di Indonesia dipengaruhi oleh perkembangan budaya yang ada di Indonesia. Setiap budaya yang berkembang disebuah wilayah pasti akan mempengaruhi hukum di daerah tersebut. Perkembangan budaya menjadi salah satu faktor perkembagan hukum di sebuah daerah. Karena setiap budaya baru pasti akan menghasilkan sistem hukum baru.

\section{Rumusan Masalah}

Berdasarkan memaparan latar belakang di atas, penulis membuat batasan rumusan masalah yaitu bagaimana ruang lingkup antropologi hukum di Indonesia beserta dinamikanya?

\section{Tujuan}

Berdasarkan pemaparan rumusan masalah di atas, tujuan penulis dalam membuat makalah ini adalah untuk mengetahui bagaimana ruang lingkup antropologi hukum di Indonesia berserta dinamikanya. 


\section{B. PEMBAHASAN}

Antropologi memiliki dua sisi holistik dimana meneliti manusia pada tiap waktu dan tiap dimensi kemanusiaannya. Arus utama inilah yang secara tradisional memisahkan antropologi dari disiplin ilmu kemanusiaan lainnya yang menekankan pada perbandingan/perbedaan budaya antar manusia. Walaupun begitu sisi ini banyak diperdebatkan dan menjadi kontroversi sehingga metode antropologi sekarang seringkali dilakukan pada pemusatan penelitian pada penduduk yang merupakan masyarakat tunggal.

Definisi Antropologi menurut para ahli:

1. William A. Havilland: Antropologi adalah studi tentang umat manusia, berusaha menyusun generalisasi yang bermanfaat tentang manusia dan perilakunya serta untuk memperoleh pengertian yang lengkap tentang keanekaragaman manusia.

2. David Hunter: Antropologi adalah ilmu yang lahir dari keingintahuan yang tidak terbatas tentang umat manusia.

3. Koentjaraningrat: Antropologi adalah ilmu yang mempelajari umat manusia pada umumnya dengan mempelajari aneka warna, bentuk fisik masyarakat serta kebudayaan yang dihasilkan

Dari definisi-definisi tersebut, dapat disusun pengertian sederhana antropologi, yaitu sebuah ilmu yang mempelajari manusia dari segi keanekaragaman fisik serta kebudayaan (cara- cara berprilaku, tradisi-tradisi, nilai-nilai) yang dihasilkan sehingga setiap manusia yang satu dengan yang lainnya berbeda-beda. Dengan, demikian antropologi merupakan hal yang mempelajari seluk-beluk yang terjadi dalam kehidupan manusia. Dapat dilihat 
dari perkembangan pada masa saat ini, yang merupakan salah dari fenomenafenomena yang terjadi ditengah- tengah masyarakat sekarang ini. Suatu spendisasi dari antropologi budaya, antropologi sosial, dan kebudayaan hukum yang menyangkut aspek hukum. Laura nades dalam bukunya "The antropologi couse study of law" pada tahun 1995.

Mengubah masalah pokok ruang lingkup antropoogi sebagai berikut:

1. Antropologi Fisik

Antropologi fisik mempelajari manusia sebagai organisme biologis yang melacak perkembangan manusia menurut evolusinya dan menyelidiki variasi biologisnya dalam berbagai jenis (spesies). Contoh: Para antropologi umumnya memiliki anggapan bahwa nenek moyang manusia adalah sejenis kera dan monyet, karena memiliki kemiripan-kemiripan tertentu.

2. Antropolgi Biologis

Merupakan bagian ilmu antropolgi yang mempelajari suatu pengertian tenteng sejarah terjadinya aneka warna makhluk manusia jika dipandang dari sudut ciri-ciri tubuhnya, baik lahir (fenotipik), seperti warna kulit, warna dan bentuk rambut, indeks tengkorak, bentuk muka, warna mata, bentuk hidung, tinggi badan dan bentuk tubuh maupun sifat bagian dalam (genotipik), seperti golongan darah dan sebagainya. Manusia dimuka bumi ini terdapat beberapa golongan berdasarkan persamaan mengenai beberapa ciri tubuh. Pengelompokkan seperti itu dalam ilmu antropologi disebut ras.

3. Antropologi Budaya 
Ruang lingkup antropologi sosial budaya lebih fokus pada kebudayaan manusia dan cara hidupnya dalam masyarakat. Menurut Haviland, ruang lingkup antropologi sosial budaya ini terbagi menjadi 3 bagian, yakni arkeologi, antropologi linguistik, dan etnologi. Menurut Burke, ruang lingkup antropologi budaya juga merupakan studi tentang praktik-praktik sosial, bentuk-bentuk ekspresif dan penggunaan bahasa. Antropologi budaya juga sering dikaitkan dengan tradisi riset dan penulisan antropologi di Amerika.

Pada abad ke-20, Franz Boas, mengajukan hasil tinjauannya terhadap asumsiasumsi antropologi evolusioner serta implikasi yang cenderung bersifat rasial. Sementara itu, antropologi sosial adalah studi yang mempelajari tentang hubungan antara manusia perorangan dan kelompok. Antropologi budaya merupakan studi komparasi mengenai cara orang-orang memahami dunia di sekitar mereka dengan metode yang berbeda-beda.

Ruang lingkup antropologi sosial juga berkaitan erat dengan sosiologi dan sejarah yang bertujuan mencari pemahaman struktur sosial dari suatu kelompok sosial yang berbeda, seperti subkultur, etnik, dan kelompok minoritas. Namun, antropologi budaya lebih berkaitan dengan filsafat, literatur atau sastra, dan seni tentang cara suatu kebudayaan mempengaruhi pengalaman seseorang dan kelompok, memberikan kontribusi untuk pemahaman yang lebih lengkap terhadap pengetahuan, adat istiadat, dan pranata masyarakat.

4. Antropologi Psikologis 
Ruang lingkup antropologi psikologis merupakan studi yang berkaitan dengan fenomena psikologi yang menggunakan istilah karakter tidak terlalu diminati oleh para peneliti. Istilah yang paling sering muncul dalam penelitian adalah istilah kepribadian, yakni culture and personality dalam konsep generik. Kedua istilah itu mengarah pada kondisi psikologis manusia, yang mana karakter bisa disamakan dengan istilah kepribadian dan bisa dikatakan bahwa karakter tergambar dari kepribadian individu

Menurut White, ruang lingkup antropologi psikologis ini mengkaji tentang hubungan antara seseorang dengan makna dan nilai kebiasaan sosial dari sistem budaya. Secara historis. antropologi psikologi erat kaitannya dengan psikoanalisis daripada psikologi eksperimental. Ruang lingkup antropologi psikologis ini penting untuk memahami fenomena karakter dalam suatu masyarakat individu. Karena, proses pembentukan dan pengembangan karakter suatu masyarakat fokus pada perkembangan dan kondisi psikologis dari manusia yang hidup dalam masyarakat tersebut. Selain itu, pengalaman individu dan lingkungan sosial juga sebuah proses yang turut berkontribusi pada pembentukan karakter manusia dalam masyarakat. Kajian antropologi psikologi juga menjadi penghubung antara studi tentang kebudayaan dan kepribadian guna menjelaskan suatu kelompok masyarakat atau suku bangsa. 


\section{Manfaat Antropologi}

1. Teoritis dapat mengetahui pegertian-pengertian hukum yang berlaku dalam masyarakat sederhana.

2. Dapat mengetahui masyarakat bisa mempertahankan nilai dasar yang dimiliki.

3. Dapat mengetahui perbedaan pendapat dan pandangan masyarakat atas waktu yang ditentukan.

4. Dapat mengetahui suku bangsa atau masyarakat yang masih kuat mempertahankan nilai budaya mereka.

5. Dapat mengetahui suku bangsa atau masyarakat norma-norma hukum yang masih tinggi. 


\section{PENUTUP}

Antropologi adalah salah satu cabang ilmu sosial yang mempelajari tentang budaya masyarakat suatu etnis tertentu. Antropologi lahir atau muncul berawal dari ketertarikan orang-orang Eropa yang melihat ciri-ciri fisik, adat istiadat, budaya yang berbeda dari apa yang dikenal di Eropa. Di antara ilmu-ilmu sosial, dan alamiah, antropologi memiliki kedudukan, tujuan, manfaat yang unik karena bertujuan dan bermanfaat dalam merumuskan penjelasan-penjelasan tentang perilaku manusia yang didasarkan pada studi atas semua aspek biologis manusia dan perilakunya di semua masyarakat. setelah di kaji kita dapat mengemukakan hasilnya bahwa manfaat di dalam antropologi hukum sangat luas. Antropologi hukum telah memberikan kontribusi yang sangat besar bagi perkembangan ilmu hukum. Dan kesimpulan yang dapat diambil adalah dimana pun kita, kita tidak akan pernah jauh dari hukum selama kita berada di negara hukum. 


\section{Daftar Pustaka}

Darmini Roza dan Laurensius Arliman S, Peran Pemerintah Daerah Di Dalam Melindungi Hak Anak di Indonesia, Masalah-Masalah Hukum, Volume 47, Nomor 1, 2018. https://doi.org/10.14710/mmh.47.1.2018.10-21

Laurensius Arliman S, Peranan Metodologi Penelitian Hukum di Dalam Perkembangan Ilmu Hukum di Indonesia, Soumatera Law Review, Volume 1, Nomor 1, 201. http://doi.org/10.22216/soumlaw.v1i1.3346.

Laurensius Arliman S, Mewujudkan Penegakan Hukum Yang Baik Di Negara Hukum Indonesia, Dialogica Jurnalica, Volume 11, Nomor 1, 2019, https://doi.org/10.28932/di.v11i1.1831.

Laurensius Arliman S, Tantangan Pendidikan Kewarganegaraan Pada Revolusi 4.0, Jurnal Ensiklopedia Sosial Review, Volume 2, Nomor 3, 2020. 